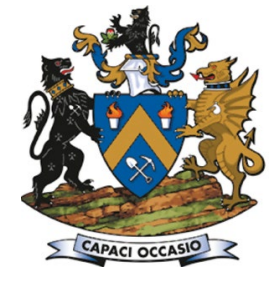

Affiliation:

1Department of Industrial Engineering, Stellenbosch University, South Africa. 2Pyrometallurgy Division, Mintek, Randburg, South Africa. ${ }^{3}$ Department of Chemical and Metallurgical Engineering, University of the Witwatersrand, Johannesburg, South Africa.

Correspondence to: H.J. Van Zyl

Email:

hman.v.zyl@gmail.com

Dates:

Received: 21 Sep. 2018 Revised: 26 Nov. 2019 Accepted: 28 Nov. 2019 Published: February 2020

How to cite:

Van Zyl, H.J., Bam, W.G., and

Steenkamp, J.D.

Identifying barriers to growth in mineral value chains.

The Southern African Insitute of Mining and Metallurgy

DOI ID:

http://dx.doi.org/10.17159/2411$9717 / 341 / 2020$

\title{
Identifying barriers to growth in mineral value chains
}

\author{
H.J. Van Zyl1', W.G. Bam¹, and J.D. Steenkamp²,3
}

\section{Synopsis}

Despite the importance that barrier identification has for policy-making and industry stakeholders alike; little guidance exists on consistent processes to systematically identify barriers that are hindering the different sectors of a value chain's expansion and growth. This article describes the development of a framework that supports the identification of barriers to growth in mineral value chains. The resultant process was applied to the case of the manganese value chain in South Africa, and revealed 31 barriers within this industry. The results were validated by a panel of experts and the feedback was used to rework and improve the framework.

\section{Keywords}

beneficiation, policy-making, barriers, manganese, case study, South Africa.

\section{Introduction}

Many of the world's mineral-rich countries are developing nations. In these countries, the mineral industry tends to make a large contribution to the annual gross domestic product and state income (UNCTAD, 2013). For these countries, it is imperative that proper mineral management strategies are put in place to ensure that the best developmental value is obtained from these industries (Bam and de Bruyne, 2017; Kahn, 2013). The various sectors comprising the mineral industry can generate a multitude of jobs, both directly and indirectly, contribute to the transfer of technologies and knowledge while also providing a substantial income (Coe, Dicken, and Hess, 2008; Gereffi and Fernandez-Stark, 2011). These developmental and economic benefits can also provide governments with the financial foundation for infrastructure development, which can lead to improved delivery of social services such as education and health care to improve the living conditions of the national citizenry (Gereffi and Fernandez-Stark, 2011; OECD, WTO, and World Bank Group, 2014).

The mineral industry, however, also has certain precarious characteristics, such as volatility, uncertainty, and exhaustibility, which pose many challenges to businesses, and policy-makers alike. A commonly stated anomaly that has been put forward is that countries with abundant natural resources often register lower economic growth than those without these natural resources (Alba, 2009; Callaghan, 2014; Department of Mineral Resources, 2011). This observation, its causes, and its validity has also given rise to a debate surrounding the possible existence of a so-called 'resource curse' and how to avoid it (Gilberthorpe and Papyrakis, 2015; Sachs and Warner, 1995; Stijns, 2005).

Within this context, beneficiation (broadly defined) is often viewed as being of strategic importance to mineral-producing countries. Specifically, beneficiation is often considered to be a key driver of industrial diversification (Bam and de Bruyne, 2017). Nonetheless, the beneficiation industries are exposed to various cyclical and systemic constraints that can hinder the ability of mineral-producing countries to establish and sustain these industries, with the capabilities that support effective mining differing from those that support effective beneficiation (Bam and de Bruyne, 2019; Hausmann, Klinger, and Lawrence, 2008). This is complicated by the constant emergence of new barriers to growth and the divergence of barriers faced by the different tiers of the mineral value chain. This makes it particularly difficult for policy-makers to firstly identify and, secondly, react to challenges that the different sectors of the mineral industry might face. In developing countries, these challenges are exacerbated by limited state resources and capacity. In many instances, and especially in developing countries, mistrust may also exist between government and industry, further complicating effective policy-making (Humphreys, 2013; Kahn, 2013). 


\section{Identifying barriers to growth in mineral value chains}

Despite the importance that being able to identify barriers has for policy-making; little guidance exists on consistent systems or frameworks which enable researchers, policy-makers, and analysts to systematically identify the barriers (in a broad sense) that are hindering expansion and growth in various sectors of a value chain and to support proactive action by policy-makers to address these barriers (Bam and de Bruyne, 2017). The development of a systematic and comprehensive framework that could enable the proactive identification of the custom sets of barriers faced in mineral value chains (MVCs) could assist policy-makers to more efficiently determine which barriers are hindering growth on a periodic basis. The aim of this research is thus to develop such a framework which supports specialized barrier analysis for each subsector in an MVC. The goal is to improve the efficiency with which researchers, policy-makers, and other stakeholders can evaluate the binding constraints on an MVC in order to formulate effective responses to address these constraints.

Given the above, this paper provides a literature review of value chain analysis approaches and the shortcomings they have concerning the identification of specific barriers to growth (Theoretical background). To address these shortcomings, a novel framework for guiding the identification of barriers in MVCs was developed and applied to a case study of manganese in South Africa. An outline of the methodology used for developing this framework is presented in the Framework development section. This is followed by an exposition of the developed framework (Framework design). The application of the framework is presented in the Case study section and the methods used to validate the framework are discussed in the Framework validation section. The paper is concluded by discussing the outcomes and implications of the research.

\section{Theoretical background}

Various methods have been employed to analyse MVCs and how governments can support them. One of the dominant frameworks used for mineral development analysis has been linkage theory, based on the work by Hirschman (1981). This has been extended to a value chain perspective by authors such as Kaplinsky, Morris, and Kaplan (2011) using the global value chain (GVC) approach based on the work by Gereffi, Humphrey, and Sturgeon (2005), among others. Other works focusing on MVCs extend linkage theory with value chain analysis and a growth pole perspective (e.g. Callaghan, 2013).

The GVC analysis framework has become an increasingly important policy analysis tool (Gereffi, 2019). It effectively links producers and consumers from around the world into an integrated analysis framework. This provides a powerful departure point for understanding increasingly global links between firms. The GVC framework specifically provides insight as to how global firms are coordinated by investigating the structure and dynamics of the role-players involved in a specific chain. This methodology is often used as a tool to trace global production, link geographically dispersed activities and roleplayers, and determine the roles they play within the industry (Gereffi and Fernandez-Stark, 2011). The basic framework consists of four basic artefacts, namely: the input-output structure (a map showing the process of transforming raw materials into final products); the geographic scope of processing activities and supply and demand of products; governance structure (which explains how value chains are controlled); and institutional context (which investigates the characteristics and attributes of the environment the value chain is embedded in) (Gereffi and Fernandez-Stark, 2011).

The VC perspective, and GVC perspective in particular, is very useful for facilitating the conceptualization of industry value chains and these frameworks have been seeing increasing use in the realm of policy analysis. The strengths of these frameworks include the fact that they:

- Provide a comprehensive description of the entire scope of the value chain (Gereffi and Fernandez-Stark, 2011; Porter, 1985)

- Identify the key role-players involved within the chain as well as the relationship they have with one another (Schmitz, 2005)

> Identify the value-adding processes within the chain (Kaplinsky and Morris, 2001); investigate the value added in different stages of the value chain (Gereffi and Fernandez-Stark, 2011; Porter, 1985)

- Describe the value chain in a global context (Gereffi and Lee, 2012)

> Include a value chain mapping structure (Gereffi and Fernandez-Stark, 2011; Kaplinsky and Morris, 2001)

- Consider chain governance structures (Humphrey and Schmitz, 2001); and consider the institutional attributes of the chain (Gereffi and Fernandez-Stark, 2011; Schmitz, 2005).

However, these approaches have certain shortcomings that need to be considered. They lack a clear purpose and structure (which allows flexibility, but requires additional analyst expertise, time, and resources); they are not consistently repeatable (particularly because they mostly rely on qualitative data and few quantitative measures have been proposed); and they specifically focus on governance and value capture issues (this implies that they potentially exclude the consideration of other factors that may also be hindering growth in the value chain). GVC (and related GPN) analysis is a suitable tool for retrospective investigation of a value chain and to identify the current extent of downstream processing (as well as the power relations between actors), but lacks a form of foresight analysis or explanations for the barriers to growth within the chain (Neilson et al., 2018).

Literature on both local and foreign mineral industries suggest that many barriers exist that prohibit economic growth in the sector (e.g. Elliot, 2015; Edinger, 2014; Ford, Hobbs, and Urquart, 2007). Despite this acknowledgement, there is no comprehensive framework that can be used systematically to identify these barriers in value chains. A simple, proven, and reliable framework would allow policy-makers to identify such barriers more efficiently. Some significant issues in this field have not been addressed:

- Often only a single sector of the value chain is investigated, without consideration of the other sectors also comprising the chain (EY, 2019; von Below, 1992)

$>$ The GVC analysis methods used in several mineral investigations do not specifically focus on the identification and prioritization of barriers

- GVC analysis and other qualitative methods are usually not systematically structured and require considerable analyst interpretation

- The data for quantitative approaches is often not available or limited, especially with regard to different sectors and developing countries (Gajigo, Mutambatsere, and Adjei, 2011; International Manganese Institute and RPA, 2015; Pooe and Mhelembe, 2014) 


\section{Identifying barriers to growth in mineral value chains}

- The scope of investigation is often too broad, restraining a full analysis of the chain and making it possible to provide only an overview of certain barriers (D'Harambure, 2015; EY, 2013)

- An analysis of the complete impact of the identified barriers is often lacking (D'Harambure, 2015; EY, 2019).

\section{Methodology overview}

Given the aim of developing a framework that supports the identification of barriers to growth in MVCs, a systematic approach was adopted in order to determine the requirements for the proposed framework (see Figure 1). Using GVC analysis literature as a basis for identifying requirements, a number of design requirements were identified, and corresponding analysis tools incorporated into the framework to address them. This framework (consisting of numerous VC analysis tools) was then applied to a comprehensive illustrative case study in order to attain insights regarding the practical application of the developed framework.

The research methodology can thus be divided into three stages:

- Framework requirement and tool identification, which includes the process of identifying the design requirements and tools required to identify barriers in the MVC (the development of the framework design requirements and potential analysis tools were based on parameters which were identified from the GVC and related literature)

- Framework design and application in order to determine the practical use of the framework in a real scenario and capture results for validation (through this exploratory case study, specific MVC characteristics were captured in a consistent and coherent manner)

- Validation of the framework performance through expert analysis of the case study and the framework itself (which enabled a review of the framework's capabilities and led to the refinement of the integrated MVC analysis process framework).

For the first step of the first phase of the methodology, the framework design requirements were identified. This was done by investigating the strengths and shortcomings of existing value chain analysis approaches through a literature review. The results of this phase are presented in the section Framework development. Supplementary tools were also identified to address the key shortcomings of the existing value chain approaches in relation to identifying barriers in MVCs. These tools were integrated within a systematic process to form an overarching framework to identify barriers for different sections comprising mineral value chains (further described in Framework design).

During the second stage, the framework was applied to the case study (the results of which are presented in the Case study section). Each framework tool, as identified in the previous stage, was applied to the South African manganese MVC. The results from each phase were gathered and analysed in order to ultimately identify the barriers to growth throughout the value chain. These barriers were then categorized according to their severity and prevalence, which revealed the top ten barriers faced in each sector of the value chain.

The final stage of the methodology consisted of validating the results and the proposed framework. The framework structure and case study results were validated through expert analysis (described in the Framework validation section). Validation questionnaires were employed, and interviews conducted with experts from diverse fields of mineral value chain analysis. Their feedback with regard to the framework's usefulness, strengths, and shortcomings was reviewed and the necessary changes were incorporated within the framework.

Figure 2 is a visual representation of the framework design process followed to determine the tools to be incorporated into the proposed framework.

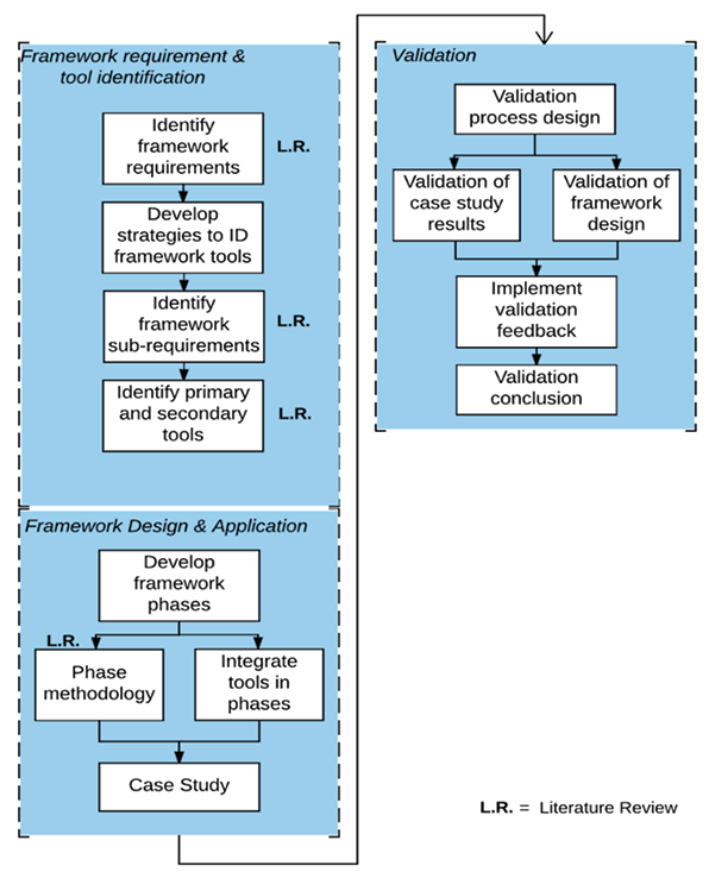

Figure 1-Overview of the implemented research methodology

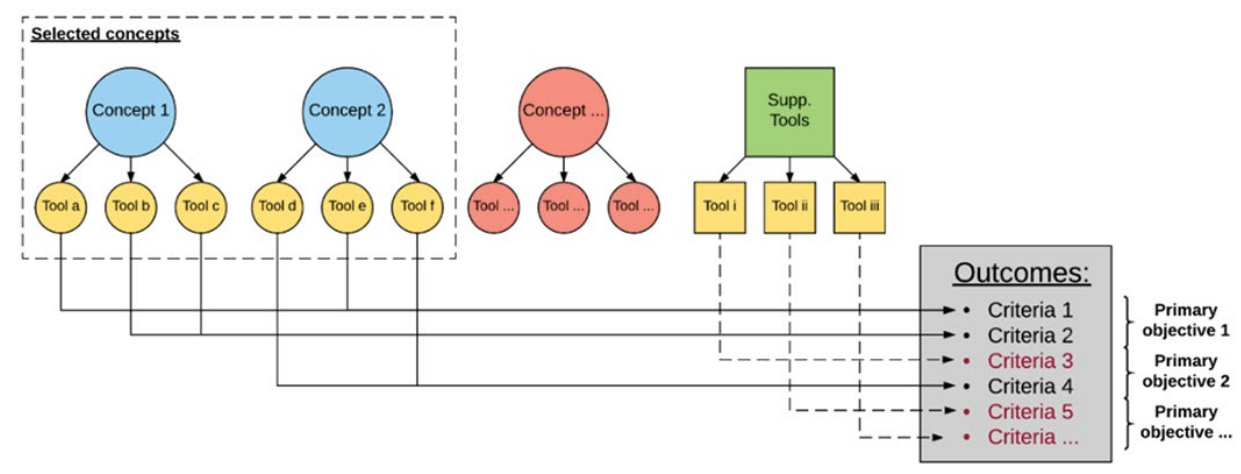




\section{Identifying barriers to growth in mineral value chains}

\section{Framework development}

The results from each of the steps included in the framework design process are described in this section, namely identifying the framework design requirements, identifying the supplementary tools, and integrating these tools in an overarching framework.

It is evident from investigating the various value chain analysis methods that each approach has characteristics that need to be investigated to ascertain its suitability for supporting the identification of barriers in MVCs. Supplementary analysis tools were also deemed necessary to address the limitations of the existing value chain analysis methods. The framework component requirements for describing an MVC were identified from the GVC and value chain literature, with new requirements proposed to address the limitations of the prevailing frameworks. These framework requirements are summarized in Table I.

\section{Framework design}

The framework consists of five phases which group specific tools together to make it more user-friendly and simpler to implement, with each phase focusing on a specific element of analysis. Table $\mathrm{X}$ in Appendix A provides an overview of the aim, detail, and outcome of each of the five phases. Once all of these phases are integrated, an overview of the proposed framework can be presented, as seen in Figure 3.

Primary data to identify barriers within the MVC can be collected by conducting interviews and surveys. This can be reliably done by following the Delphi technique. The technique aims to achieve a convergence of opinion on a specific real-world issue through a group communication process. The data collected from the interviews can then be used to compile a comprehensive list of sector-specific barriers across the industry. Each round of the Delphi process as implemented in the exploratory case study is summarized in Table XI in Appendix B.

Once the barriers have been identified from the Delphi process, these barriers can be analysed by assessing their severity and prevalence, classifying them according to priority, reviewing the high-priority barriers, and determining the causal factors of the high-priority barriers. The implementation of these steps is further clarified in the case study section that follows.

\section{Case study}

This section reviews the case selection rationale and presents the results of the case study according to the five phases of the framework. The South African manganese industry was selected as a case study for the following reasons:

- Manganese has significant commercial importance, especially for the production of steel. Thus the results gathered from the case study will be of significant value

- Manganese is mainly used as an alloying element, hence this industry is analogous to many other mineral industries, such as chrome and iron, which are also primarily used in the manufacturing of alloys for steel

- South Africa is major player in the manganese industry, making information for the study more accessible and readily available

> Manganese is predominantly used only in steel manufacturing, which limits the product scope and simplifies the analysis required for the study.

An international perspective was also incorporated into the study to determine South Africa's global market presence. Since the entire value chain is very extensive and becomes increasingly intricate further down the chain, the scope of the value chain analysis was limited to activities involving the primary processing of the ore for product manufacturing. Each

Table I

\section{Framework requirements}

\begin{tabular}{|c|c|c|}
\hline $\begin{array}{l}\text { Strategic framework } \\
\text { requirement no. }\end{array}$ & Requirement & Rationale and source \\
\hline SFR1 & Background knowledge on the specific mineral industry & Proposed to provide a knowledge base of the MVC that is to be investigated \\
\hline SFR2 & Identification of activities in the value chain & Key to describing value chain. Builds on Porter's value chain approach (Porter, 1985) \\
\hline SFR3 & Identification of the value chain role-player structure & $\begin{array}{l}\text { Key to describing value chain. Builds on Porter's value chain (Porter, 1985) and GVC } \\
\text { analysis (Gereffi and Fernandez-Stark, 2011; Gereffi, Humphrey, and Sturgeon, 2005) }\end{array}$ \\
\hline SFR4 & Identification of the different sectors comprising the industry & Proposed to enable the identification of sector-specific barriers \\
\hline SFR5 & $\begin{array}{l}\text { Identification of the process-level flow of inputs, outputs, and } \\
\text { intermediate products in the value chain }\end{array}$ & $\begin{array}{l}\text { Proposed to elaborate upon Porter's value chain (Porter, 1985) in order to reveal the } \\
\text { relationships among the role-players involved in the MVC through modelling the } \\
\text { industry's high-level interaction between the various stakeholder involved }\end{array}$ \\
\hline SFR6 & Evaluation of domestic industry's global market position & $\begin{array}{l}\text { Key to understanding context of barriers. Builds on GVC analysis (Gereffi, 2011; } \\
\text { Gereffi and Fernandez-Stark, 2011; Sturgeon and Gereffi, 2009) }\end{array}$ \\
\hline SFR7 & $\begin{array}{l}\text { Evaluation of the geographic scope of operations in } \\
\text { the mineral value chain }\end{array}$ & $\begin{array}{l}\text { Key to understanding context of barriers. Builds on GVC analysis (Gereffi, 2011; } \\
\text { Gereffi and Fernandez-Stark, 2011) }\end{array}$ \\
\hline SFR8 & Evaluation of the power relationship between role-players & $\begin{array}{l}\text { Key to understanding context of barriers. Builds on GVC analysis (Gereffi, 1994; } \\
\text { Gereffi and Fernandez-Stark, 2011; Gereffi, Humphrey, and Sturgeon, 2005) }\end{array}$ \\
\hline SFR9 & Evaluation of the industry's current state of affairs & $\begin{array}{l}\text { Proposed in order to gain an initial qualitative understanding of the impact that the } \\
\text { barriers have on the industry, as well as to determine their possible causes }\end{array}$ \\
\hline SFR10 & $\begin{array}{l}\text { Identification of the latest barriers across the different } \\
\text { sectors in the value chain }\end{array}$ & \multirow{5}{*}{$\begin{array}{l}\text { Additional framework requirements to address the research objective of identifying } \\
\qquad \text { barriers to growth in mineral value chains }\end{array}$} \\
\hline SFR11 & Evaluation of the severity of the barriers & \\
\hline SFR12 & Evaluation of the prevalence of the barriers & \\
\hline SFR13 & Analysis of cross-sector results & \\
\hline SFR14 & Categorization of barriers & \\
\hline
\end{tabular}




\section{Identifying barriers to growth in mineral value chains}

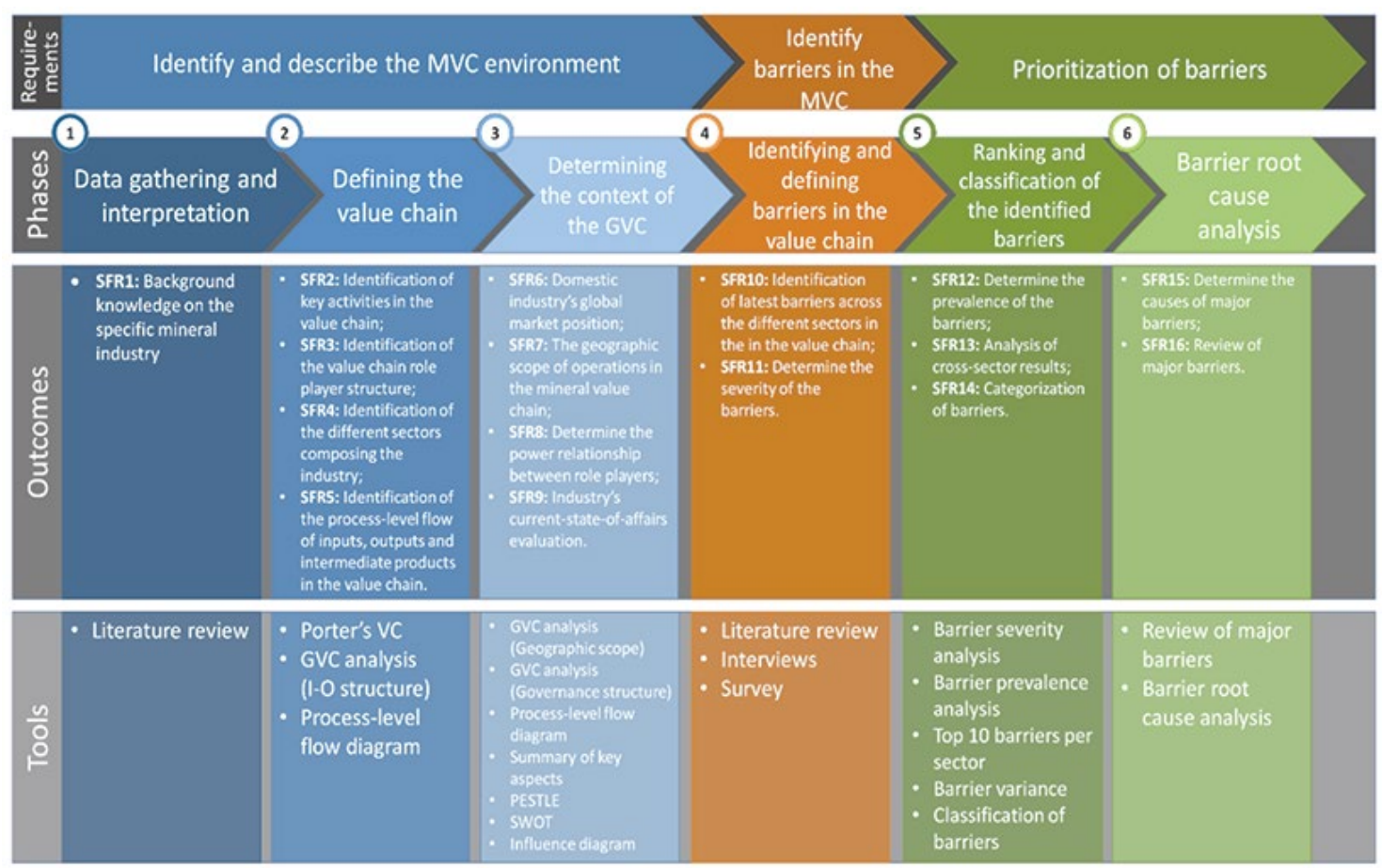

Figure 3-Proposed framework to guide the process of identifying barriers in MVCs

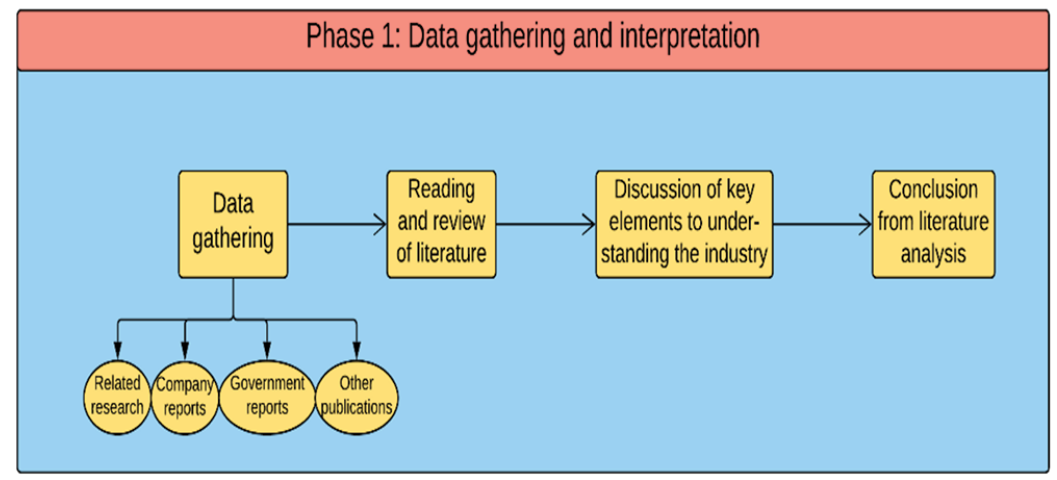

Figure 4-Overview of Phase 1 of the proposed framework

of the value chain activities up to this point formed part of the analysis and description of the MVC environment. This scope was deemed to be broad enough to illustrate and test the framework's capabilities, without the study becoming unduly complex. The rest of this section presents the results from the case study according to the five phases of the framework.

\section{Phase 1: Data gathering and interpretation}

A literature review was conducted on the manganese industry, specifically within the context of the South African market, which provided an overview of the relevant background information, disciplines, and theories relating to the specific industry. This information was used firstly to provide a solid platform to understanding the various aspects of the industry. An overview of the methodology followed in this phase is presented in Figure 4.

Since the literature review on the South African manganese value chain included a great deal of information, only the major findings are summarized here. South Africa is the dominant producer of manganese, possessing between 75 and $80 \%$ of the world's identified resources and approximately $24 \%$ of the world's reserves. Over $90 \%$ of the reserves are located in the Kalahari Manganese Field (KMF) located in the Northern Cape Province, which has an estimated 4 Gt of manganese reserves (Ratshomo, 2013). The primary use of manganese is in manufacturing alloys that are used in steel production (International Manganese Institute and RPA, 2015). High-carbon ferromanganese, refined ferromanganese, and silicomanganese, are the major manganese alloys produced in South Africa (International Manganese Institute, 2014a; Olsen, Tangstad, and Lindstad, 2007). Manganese is also used to a lesser extent in the production of batteries, and very small quantities are used in numerous chemical products (Gajigo, Mutambatsere, and Adjei, 2011; International Manganese Institute and RPA, 2015).

\section{Phase 2: Defining the MVC}

During this phase, the various activities comprising the value chain were identified, as well as the role-player structures for each segment of the chain. A process flow diagram was developed, which provides an overview of the entire chain and the products that are produced throughout. The steps in this phase are illustrated in Figure 5. 


\section{Identifying barriers to growth in mineral value chains}

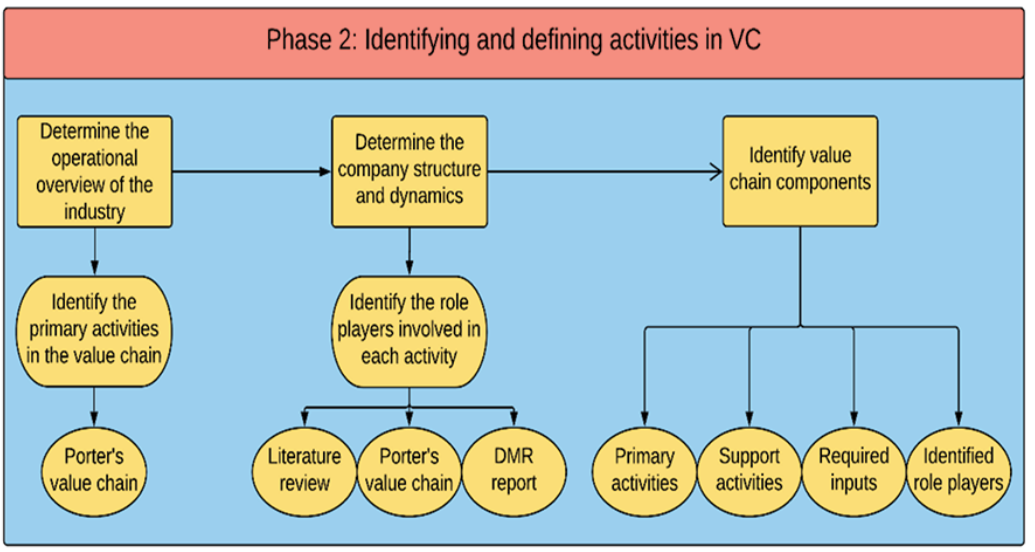

Figure 5-Overview of Phase 2 of the proposed framework

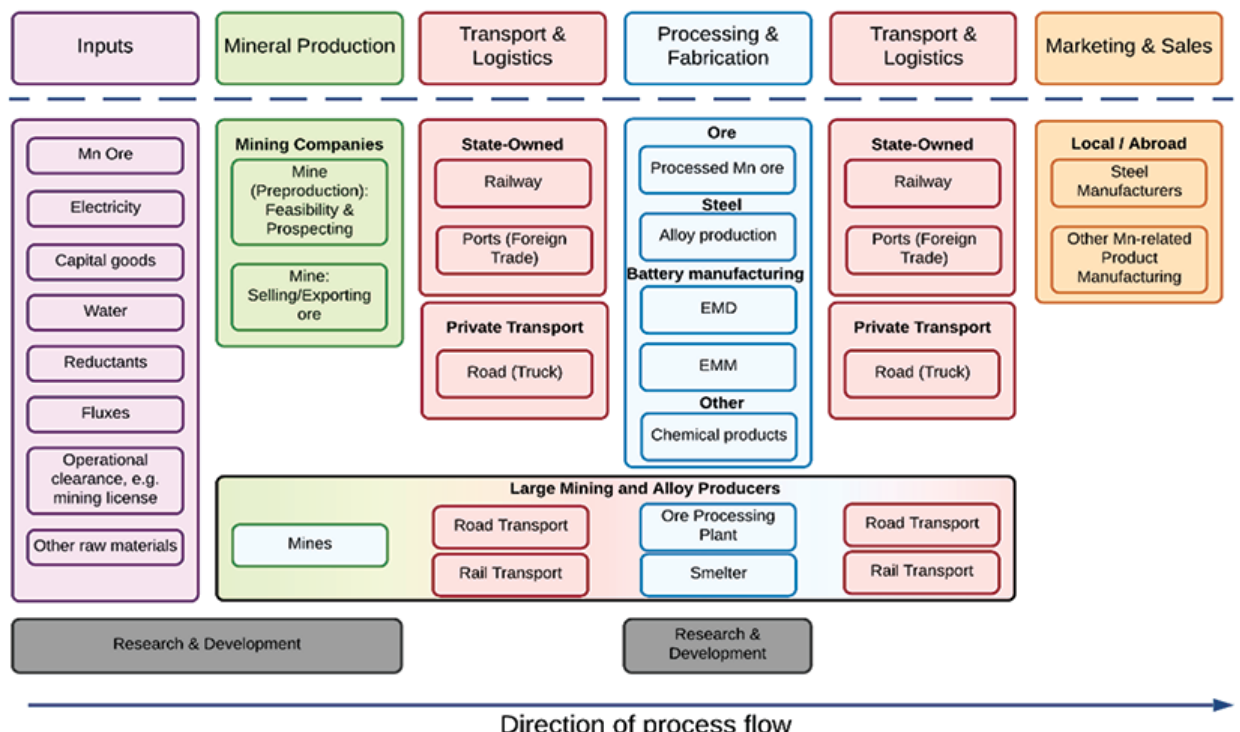

Figure 6-The South African manganese value chain

Porter's value chain and Gereffi's input-output structure approaches served as the foundation for developing the manganese MVC. Figure 6 outlines the various segments of the South African manganese value chain and the types of roleplayers involved in each step. It also provides a representation of the local structure of the industry, the required inputs for the processes, and the activities involved in each segment.

A process-level flow diagram was also developed in this phase to illustrate how materials are transformed throughout the value chain in terms of inputs and outputs. This diagram reveals the relationships among and between the various sectors and role-players in the manganese mineral industry. The small white blocks represent a specific output or product, which in turn, in most cases, is the input to the next process. These products are grouped by colours that represent different product types. The products are connected through arrows which indicate the process flow. It is useful to add the size (volume) of each output to the diagram, if this information is available, in order to place the proportion of these outputs into perspective. The final processlevel diagram is shown in Figure 7.

The various sectors of the manganese industry are easily identifiable in the diagram. The industry consists of:
- Ore / mineral production

> Non-ferrous, electrolytic manganese dioxide, (EMD) and electrolytic manganese metal (EMM) production

- Ferrous / alloy manufacturing

- Slag-related product manufacturing

> Steel manufacturing

> Other chemical product manufacturing.

Due to the fact that the majority of manganese is used for metallurgical purposes (with 90 to $95 \%$ used in alloy manufacturing and approximately 5\% in EMD and EMM production), the sectors that were investigated in this industry were: mineral production (mining sector), alloy manufacturing, EMD production, and EMM production.

\section{Phase 3: Determining the context of the global value chain}

This phase focused on integrating the manganese MVC within a global context by analysing the essential characteristics that define the chain environment. The activities in the phase are summarized in Figure 8.

To understand South Africa's position in the global manganese industry, the context of the country's role, and where 


\section{Identifying barriers to growth in mineral value chains}

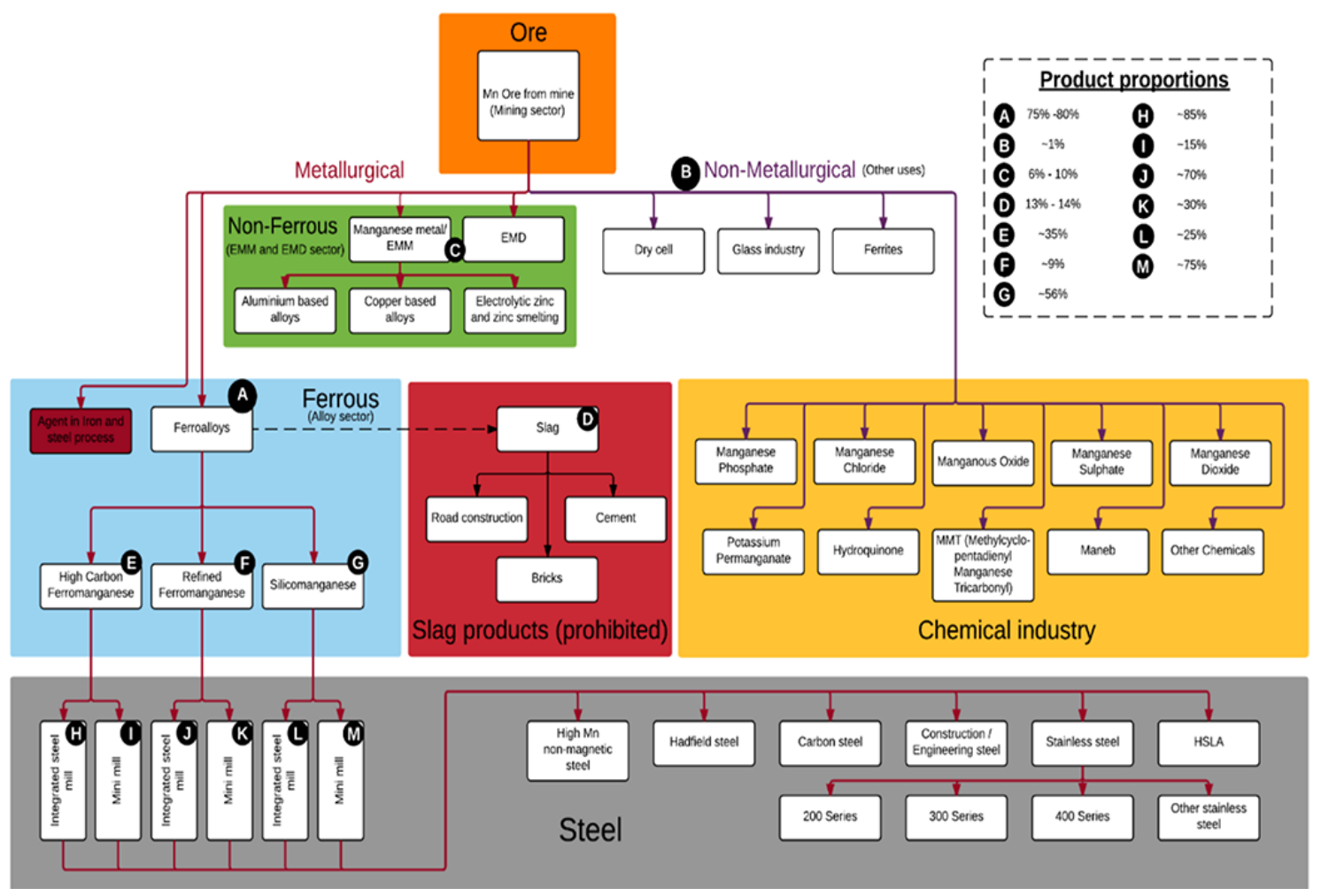

Figure 7-Manganese industry process-level flow diagram (van Zyl, Bam, and Steenkamp, 2016)

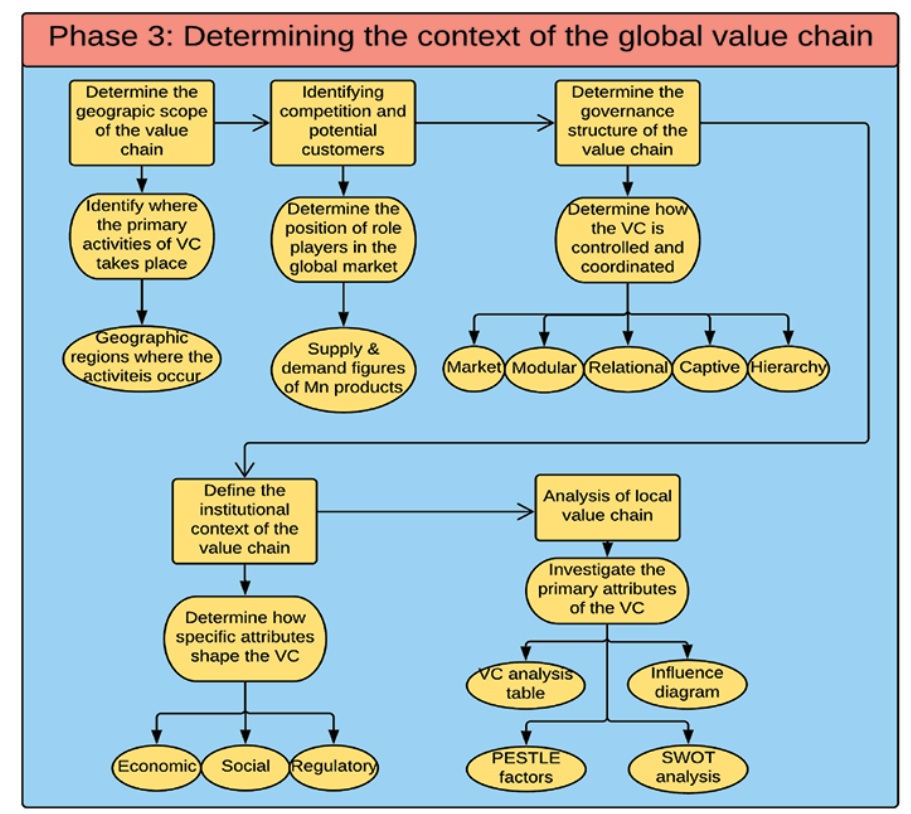

Figure 8-Overview of Phase 3 of the proposed framework

the barriers to economic growth lie, the global value chain of manganese and manganese-related products was examined. The findings are shown in Table II.

Table III lists the major global producers of manganeserelated products and the total of number of countries producing each product.

Since manganese alloy producers do not have a differentiation advantage over competitors, as the alloys are commonly used in steel and widely produced around the world, they must focus primarily on gaining a cost advantage in order to improve their competitive advantage. This primarily results in the top of the chain taking on a 'market' structure (as defined in Table IV). Producers are thus under pressure to constantly adjust their business strategy to cut costs, and one way of doing this is by ensuring they have the best trade agreement with ore providers, which places mining companies in a stronger trade position. This is highlighted by the fact that alloy producers also have to contend with rising electricity tariffs, labour issues, and other operational costs which are currently a number of South Africa's largest barriers to growth. 


\section{Identifying barriers to growth in mineral value chains}

\begin{tabular}{|c|c|c|c|c|c|c|}
\hline \multirow[t]{2}{*}{ Product } & \multicolumn{3}{|c|}{ Production } & \multicolumn{3}{|c|}{ Consumption } \\
\hline & Global rank & Volume (Mt Mn units) & $\%$ of global total & Global rank & Volume (Mt Mn units) & $\%$ of global total \\
\hline Mn ore & 1 & 4.64 & 24.9 & 9 & 0.325 & 1.8 \\
\hline HC FeMn & 3 & 0.457 & 10.1 & 28 & 0.27 & 0.56 \\
\hline Ref. FeMn & 5 & 0.102 & 5.9 & 31 & 0.10 & 0.59 \\
\hline SiMn & 14 & 0.134 & 1.0 & 30 & 0.30 & 0.22 \\
\hline Steel & 21 & 7.22 & 0.45 & 221 & 5.40 & 0.36 \\
\hline
\end{tabular}

Sources: International Manganese Institute, 2014b; World Steel Association, 2014

Table III

Countries producing manganese-related products

\begin{tabular}{|c|c|c|c|c|c|c|c|c|c|c|}
\hline \multirow[t]{2}{*}{ Country } & \multicolumn{3}{|c|}{ Ore } & \multicolumn{3}{|c|}{ Alloys } & \multirow[t]{2}{*}{ Slag products } & \multirow[t]{2}{*}{ Steel } & \multirow[t]{2}{*}{ EMD } & \multirow[t]{2}{*}{ EMM } \\
\hline & Low & Med & High & HCFeMn & Ref. FeMn & SiMn & & & & \\
\hline South Africa & $x$ & $\checkmark$ & $\checkmark$ & $\checkmark$ & $\checkmark$ & $\checkmark$ & $x$ & $\checkmark$ & $X^{1}$ & $\checkmark$ \\
\hline China & $\checkmark$ & $x$ & $x$ & $\checkmark$ & $\checkmark$ & $\checkmark$ & $\checkmark$ & $\checkmark$ & $\checkmark$ & $\checkmark$ \\
\hline USA & $x$ & $x$ & $x$ & $\checkmark$ & $\checkmark$ & $\checkmark$ & $\checkmark$ & $\checkmark$ & $\checkmark$ & $x$ \\
\hline Australia & $X$ & $\checkmark$ & $\checkmark$ & $\checkmark$ & $x$ & $\checkmark$ & $\checkmark$ & $\checkmark$ & $\checkmark$ & $x$ \\
\hline Brazil & $\checkmark$ & $\checkmark$ & $\checkmark$ & $\checkmark$ & $\checkmark$ & $\checkmark$ & $\checkmark$ & $\checkmark$ & $x$ & $x$ \\
\hline Ukraine & $x$ & $\checkmark$ & $x$ & $\checkmark$ & $\checkmark$ & $\checkmark$ & $\checkmark$ & $\checkmark$ & $x$ & $x$ \\
\hline Gabon & $x$ & $\checkmark$ & $\checkmark$ & $x$ & $x$ & $x$ & $\checkmark$ & $x$ & $x$ & $x$ \\
\hline Japan & $x$ & $x$ & $x$ & $\checkmark$ & $\checkmark$ & $\checkmark$ & $\checkmark$ & $\checkmark$ & $\checkmark$ & $x$ \\
\hline India & $\checkmark$ & $\checkmark$ & $\checkmark$ & $\checkmark$ & $\checkmark$ & $\checkmark$ & $x$ & $\checkmark$ & $x$ & $x$ \\
\hline South Korea & $x$ & $x$ & $x$ & $\checkmark$ & $\checkmark$ & $\checkmark$ & $\checkmark$ & $\checkmark$ & $x$ & $x$ \\
\hline Total producing countries & 9 & 16 & 6 & 21 & 11 & 21 & -2 & 91 & 8 & 2 \\
\hline
\end{tabular}

Sources: Ore and alloys (International Manganese Institute, 2014a), slag (FICCI, 2014; Global Slag, 2015), Steel (World Steel Association, 2014), EMD (US International Trade Commission, 2003), EMM (MMC, 2016), Interviews.

'South Africa stopped EMD production in 2015.

${ }^{2}$ No data available on countries that manufacture products from ferro-slag.

Table IV

Key characteristics of global value chain governance (source: (Gereffi, Humphrey, and Sturgeon, 2005)

\begin{tabular}{|l|c|c|c|}
\hline $\begin{array}{l}\text { Value chain governance } \\
\text { type }\end{array}$ & $\begin{array}{c}\text { Complexity of } \\
\text { transactions }\end{array}$ & $\begin{array}{c}\text { Ability to codify } \\
\text { transactions }\end{array}$ & $\begin{array}{c}\text { Capabilities in the } \\
\text { supply base }\end{array}$ \\
\hline Market & Low & High & High \\
Modular & High & High & Low \\
\hline
\end{tabular}

Further down the chain, however, a modular structure becomes apparent (as defined in Table IV) since complex transactions occur that are relatively easy to codify. This translates to downstream products such as ferroalloys, EMD, and EMM, which are made to the customer's specifications and the suppliers spread investments across a wide customer base. Switching costs are still low even though buyer-supplier interactions can be very complex. Unlike in simple markets, the linkages or relationships between partners are more substantial due to the higher volume of information flowing between them.

The final step of Phase 3 deals with the key attributes specific to the manganese value chain. Such factors include technology usage, capital requirements, workforce characteristics, and operational technology. The investigation of these attributes often leads to the discovery of where the bottlenecks, process inefficiencies, and general opportunities for improvement lie in the value chain. The tools for this analysis entail a summary of the key aspects in the value chain, which are elaborated upon through a PESTLE factor analysis and SWOT analysis of the manganese industry. A summary of the key aspects of the South African manganese constraints are provided in Table V.

\section{Phase 4: Identifying and defining barriers in the MVC}

Figure 9 presents an overview of the activities of Phase 4. Interviews were conducted with experts representing individuals from different sectors of the chain within the manganese mineral industry to identify its barriers. The barriers were then defined, and a survey conducted to determine the impact that each barrier has on each sector.

Semi-structured interviews were conducted with the aim of gaining comparable views of the most pressing issues in the industry faced by various role-players in different sectors of the manganese value chain. Representatives of the mining, alloy, EMD, and EMM sectors were approached. These included representatives from two of the largest manganese mining companies in the world, two of the four South African manganese alloy producers, representing both ferromanganese and silicomanganese operations, and the world's only non-China 


\section{Identifying barriers to growth in mineral value chains}

Table $V$

Summary of key aspects in the manganese value chain

\begin{tabular}{|c|c|c|c|c|}
\hline & Mineral production & Alloy production & EMD production & EMM production \\
\hline Primary input required & Capital, labour, equipment & $\begin{array}{l}\text { Electricity, labour, ore, } \\
\text { reductants, fluxes }\end{array}$ & $\begin{array}{l}\text { Electricity, labour, ore, } \\
\text { process chemicals }\end{array}$ & $\begin{array}{l}\text { Electricity, labour, ore, process } \\
\text { chemicals }\end{array}$ \\
\hline Type of product outputs & $\begin{array}{c}\text { Low }(<30 \% \mathrm{Mn}), \text { medium } \\
(\geq 30 \% \text { and }<44 \%) \text { and high } \\
\text { grade ore }(\geq 44 \%)\end{array}$ & $\begin{array}{l}\text { HCFeMn, Ref. FeMn, } \\
\text { SiMn }\end{array}$ & EMD & EMM \\
\hline Capital requirements & $\begin{array}{l}\text { High since these are large } \\
\text { mining operations }\end{array}$ & $\begin{array}{l}\text { Medium to high. Capital } \\
\text { requirements are similar to other } \\
\text { mineral processing facilities }\end{array}$ & High & High \\
\hline Return to scale effects & $\begin{array}{l}\text { Must be big mining operation } \\
\text { to be profitable }\end{array}$ & $\begin{array}{l}\text { Since it is directly linked with the mining } \\
\text { sector, the scaling effects are similar }\end{array}$ & $\begin{array}{l}\text { Scaling effects are important } \\
\text { since high volumes of Mn ore is } \\
\text { required for production }\end{array}$ & $\begin{array}{l}\text { Scaling effects are important } \\
\text { since high volumes of Mn ore is } \\
\text { required for production }\end{array}$ \\
\hline $\begin{array}{l}\text { Nature of technologic } \\
\text { requirements }\end{array}$ & Widely available & Widely available & $\begin{array}{l}\text { Sophisticated, production is restricted } \\
\text { to a few countries. The only Africa- } \\
\text { based producer's processes were } \\
\text { discontinued in } 2015\end{array}$ & $\begin{array}{l}\text { Very sophisticated (only } \\
\text { producer outside of China and } \\
\text { only producer globally which } \\
\text { produces it selenium-free, which } \\
\text { is a superior product) }\end{array}$ \\
\hline Labour requirements & $\begin{array}{l}\text { High labour intensity consisting } \\
\text { of low-skilled workers and a few } \\
\text { highly skilled employees in } \\
\text { planning and managerial positions }\end{array}$ & $\begin{array}{c}\text { Workforce consisting of a large } \\
\text { group semi-skilled workers and few } \\
\text { very skilled workers }\end{array}$ & $\begin{array}{l}\text { Small to medium sized workforce, } \\
\text { typically consisting of larger group } \\
\text { semi-skilled workers and smaller } \\
\text { group of very skilled workers }\end{array}$ & $\begin{array}{l}\text { Small to medium sized workforce, } \\
\text { typically consisting of larger group } \\
\text { semi-skilled workers and smaller } \\
\text { group of very skilled workers }\end{array}$ \\
\hline Transport cost of inputs & Very little & Very high & Very high & Very high \\
\hline Transport cost of outputs & $\begin{array}{l}\text { Very high (seen as highest } \\
\text { operational cost) }\end{array}$ & Very high & High & High \\
\hline $\begin{array}{l}\text { Role of local transport } \\
\text { infrastructure }\end{array}$ & $\begin{array}{l}\text { Very high, it is controlled by state- } \\
\text { owned Transnet. Rail capacity is } \\
\text { allocated between different } \\
\text { companies that want to make } \\
\text { use of the railways. Transnet } \\
\text { controls the allocation that each } \\
\text { company receives. }\end{array}$ & $\begin{array}{l}\text { Very high, it is controlled by state-- } \\
\text { owned Transnet. Rail capacity is } \\
\text { allocated between different companies } \\
\text { that want to make use of the railways. } \\
\text { Transnet controls the allocation that each } \\
\text { company receives. }\end{array}$ & High & High \\
\hline Size of local supply & $\begin{array}{c}\text { SA is the largest global producer } \\
\text { of manganese (China is a } \\
\text { close second) }\end{array}$ & $\begin{array}{l}\text { SA is one of the largest global producers } \\
\text { of HCFeMn and ref. FeMn alloys, but is } \\
\text { much smaller than to China. SA is } \\
\text { however in the top } 2 \text { largest exporters } \\
\text { of these alloys }\end{array}$ & $\begin{array}{l}\text { Local production discontinued } \\
\text { in } 2015\end{array}$ & $\begin{array}{l}\text { SA only producer outside } \\
\text { of China }\end{array}$ \\
\hline Primary competitors & $\begin{array}{l}\text { Primarily China, Australia, } \\
\text { Gabon, Brazil, India }\end{array}$ & $\begin{array}{c}\text { China, India, Japan, South Korea, } \\
\text { Ukraine (SiMn) }\end{array}$ & $\begin{array}{l}\text { China, USA, Australia, Greece, } \\
\text { Ireland, Japan, Belgium }\end{array}$ & China \\
\hline Destinations of exports & $\begin{array}{c}\text { Primarily China and India, but also } \\
\text { includes Russia and other } \\
\text { countries in Asia }\end{array}$ & $\begin{array}{c}\text { Primarily the USA, but also includes India, } \\
\text { countries in Europe, South America, } \\
\text { and Asia }\end{array}$ & $\begin{array}{l}\text { Europe, USA, Africa, } \\
\text { Japan, Asia }\end{array}$ & $\begin{array}{c}\text { Primarily the USA, Japan and } \\
\text { countries in Europe, but also } \\
\text { includes Taiwan, South America, } \\
\text { Canada and Africa }\end{array}$ \\
\hline $\begin{array}{l}\text { Largest operational } \\
\text { expenditures }\end{array}$ & Logistics, equipment, labour & Ore / raw materials, electricity, labour & Ore, labour, electricity & Electricity, labour \\
\hline
\end{tabular}

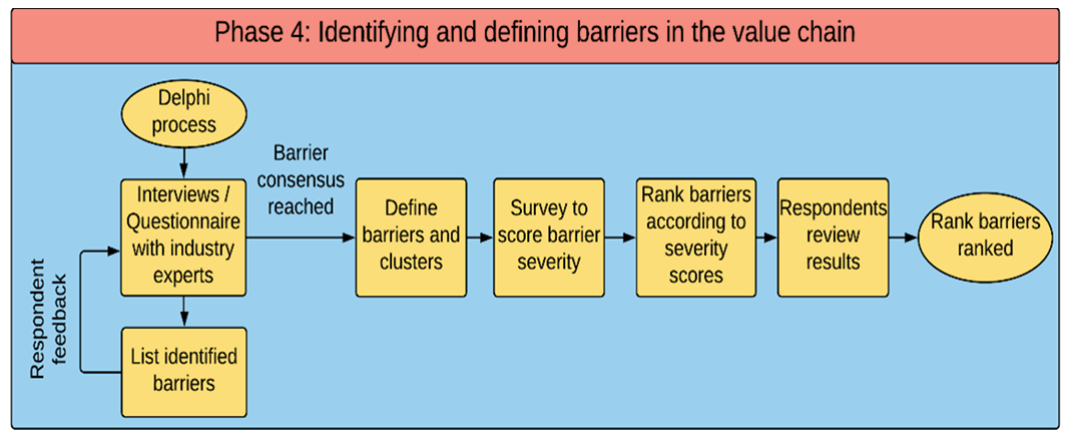

Figure 9-Overview of Phase 4 of the proposed framework

based producer of EMM and Africa's only producer of premiumquality EMD. Table VI summarizes the sampling of data.

The barriers identified from the literature were added to those identified directly by the respondents to form a list of 31 barriers and 9 barrier clusters, as indicated in Table VII. Questionnaires were completed by the participants (from the mining, alloy production, EMD, and EMM sectors) in which they gave a score out of 10 for each of the 31 identified barriers (where zero represented no impact and 10 a very high impact). Table VII outlines the identified barriers. 


\section{Identifying barriers to growth in mineral value chains}

\section{Table VI}

Sampling and sourcing of data

\begin{tabular}{|l|c|c|c|c|c|c|}
\hline Role-player type & Interview & Questionnaire & Public records & Survey & Could not reach & Identified producers in sector \\
\hline Mining & 2 & 2 & 6 & 3 & 9 \\
Alloy production & 2 & 2 & 4 & 3 & 0 \\
EMD production & 1 & 1 & 1 & 1 & 0 \\
EMM production & 1 & 1 & 12 & 1 & 0 \\
Total sources & 6 & 6 & 8 & 1 \\
\end{tabular}

\section{Table VII}

\section{List of identified barriers in the South African manganese industry}

\begin{tabular}{|c|c|c|c|c|c|c|c|c|}
\hline $\begin{array}{l}\text { Sustained } \\
\text { development }\end{array}$ & $\begin{array}{l}\text { Insufficient physical } \\
\text { infrastructure }\end{array}$ & Labour & $\begin{array}{l}\text { Regulations / } \\
\text { policies }\end{array}$ & $\begin{array}{l}\text { Market } \\
\text { conditions }\end{array}$ & $\begin{array}{c}\text { Resource } \\
\text { management }\end{array}$ & $\begin{array}{l}\text { Electricity } \\
\text { concerns }\end{array}$ & $\begin{array}{l}\text { Social } \\
\text { issues }\end{array}$ & $\begin{array}{l}\text { Management- } \\
\text { related }\end{array}$ \\
\hline $\begin{array}{l}\text { Restricted access } \\
\text { to capital }\end{array}$ & $\begin{array}{l}\text { Underdeveloped } \\
\text { infrastucture } \\
\text { and facilities }\end{array}$ & $\begin{array}{l}\text { Rising cost } \\
\text { of labour }\end{array}$ & $\begin{array}{l}\text { Resource } \\
\text { nationalism }\end{array}$ & $\begin{array}{c}\text { Market } \\
\text { volatility }\end{array}$ & $\begin{array}{l}\text { Access to } \\
\text { water }\end{array}$ & $\begin{array}{l}\text { Unreliable } \\
\text { supply }\end{array}$ & $\begin{array}{l}\text { Social license } \\
\text { to operate }\end{array}$ & $\begin{array}{l}\text { Lack of policy } \\
\text { implementation }\end{array}$ \\
\hline Technology & $\begin{array}{l}\text { Lack of railway } \\
\text { capacity }\end{array}$ & $\begin{array}{l}\text { Unrest / volatility } \\
\text { in workforce }\end{array}$ & $\begin{array}{l}\text { Mining Charter } \\
\text { concerns }\end{array}$ & $\begin{array}{l}\text { Fluctuations in } \\
\text { exchange rate }\end{array}$ & $\begin{array}{l}\text { Competing } \\
\text { demands } \\
\text { for land use }\end{array}$ & $\begin{array}{l}\text { Rising } \\
\text { tariffs }\end{array}$ & & $\begin{array}{c}\text { Poor corporate } \\
\text { project execution } \\
\text { and mismanagement }\end{array}$ \\
\hline \multirow[t]{4}{*}{$\begin{array}{l}\text { Lack of research } \\
\text { and development } \\
\text { and innovation }\end{array}$} & $\begin{array}{c}\text { Lack of } \\
\text { port } \\
\text { facilities }\end{array}$ & $\begin{array}{l}\text { Low productivity } \\
\text { of workforce }\end{array}$ & $\begin{array}{l}\text { Obtaining mining } \\
\text { license }\end{array}$ & $\begin{array}{c}\text { Competition / } \\
\text { global oversupply }\end{array}$ & $\begin{array}{l}\text { Scarcity of } \\
\text { resources }\end{array}$ & & & Low efficiency \\
\hline & $\begin{array}{l}\text { Increasing transport } \\
\text { costs }\end{array}$ & Skills shortage & $\begin{array}{l}\text { Disposal } \\
\text { of slag }\end{array}$ & $\begin{array}{l}\text { Sizeable domestic } \\
\text { market / proximity } \\
\text { to market }\end{array}$ & $\begin{array}{l}\text { Environmental } \\
\text { concerns }\end{array}$ & & & \\
\hline & & & & Anti-dumping duty & & & & \\
\hline & & & & Geopolitical uncertainty & & & & \\
\hline
\end{tabular}

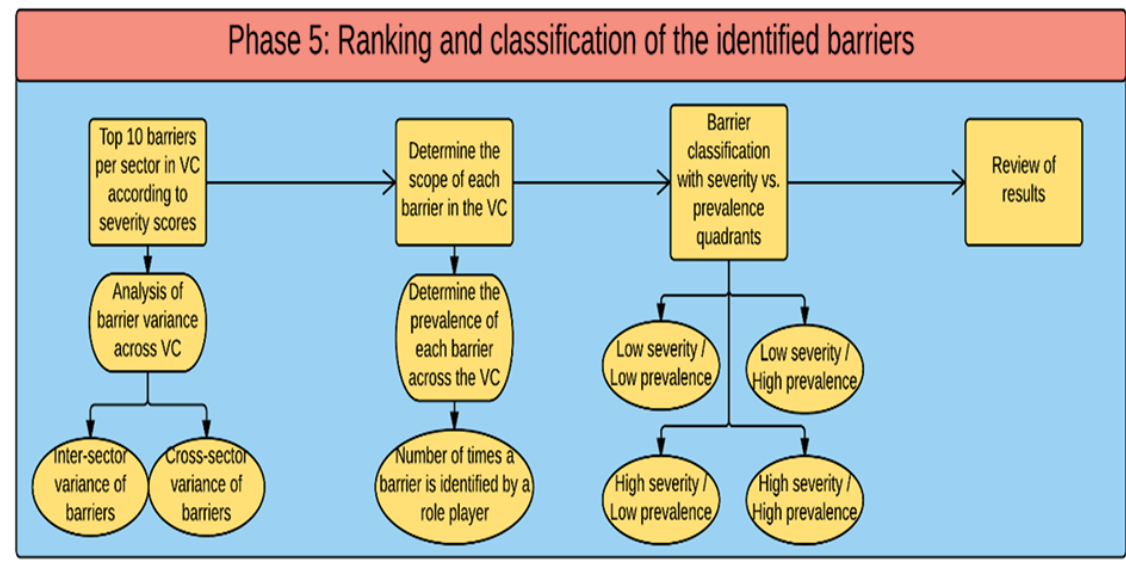

Figure 10-Overview of Phase 5 of the proposed framework

\section{Phase 5: Ranking and classification of the identified barriers}

During this phase, all of the data gathered from the industry experts was analysed to determine the impact that each barrier has on specific sectors within the value chain and how widespread the impact of the barrier is throughout the industry. The phase is outlined in Figure 10.

The severity of the barriers was based on the scale of the impact on the value chain and suppression of growth. The top ten most severe barriers in each sector of the value chain were then identified based on the expert rankings as shown in Table VIII.

The prevalence of the barriers was determined by evaluating how widespread the various barriers were as identified by the experts in the different segments of the value chain. This was calculated by determining the number of respondents that identified the barrier in their list of top ten barriers. To ensure that all of the sectors were represented fairly, these numbers were normalized by using the sector's average prevalence, so that each sector was weighted equally. This prevented the number of respondents per sector from influencing the prevalence. In other words, sectors with few representatives, such as EMD and EMM, are represented equally with respect to the other sectors. The weighted prevalence and average severity scores for each of the identified barriers (out of a score of five) are shown in Table IX.

After the severity and prevalence of the identified barriers in the manganese industry had been investigated, the barriers could be classified in one of four groups. By grouping these barriers together, it was possible to assign a level of priority to each one, 


\section{Identifying barriers to growth in mineral value chains}

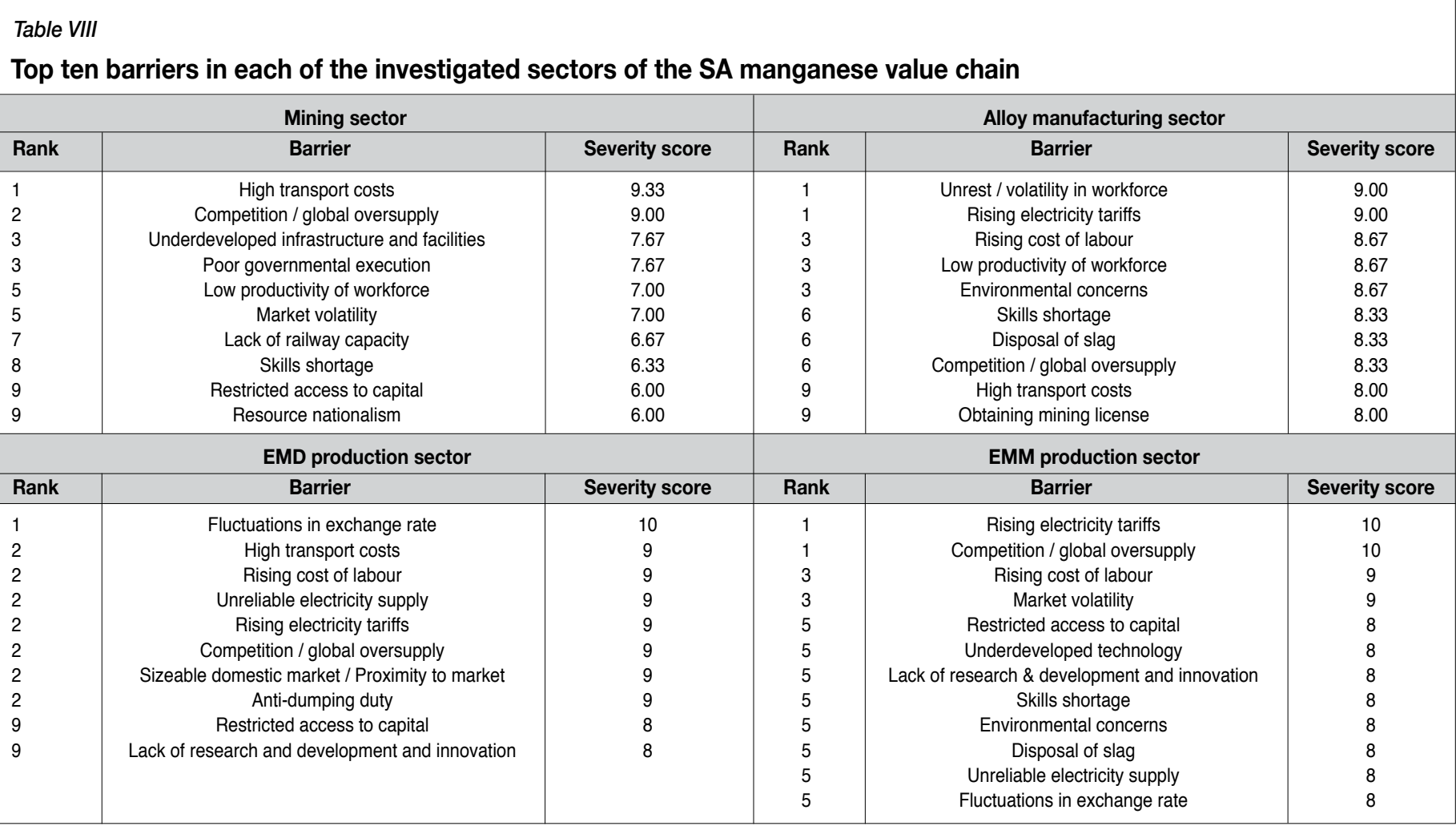

Table IX

Prevalence and severity scores of the identified barriers

\begin{tabular}{|c|c|c|c|c|c|}
\hline Barrier & Prevalence & Severity & Barrier & Prevalence & Severity \\
\hline Competition / global oversupply & 4.58 & 4.54 & Underdeveloped infrastructure & 1.67 & 2.88 \\
\hline Rising electricity tariffs & 3.75 & 4.17 & Poor governmental execution & 1.67 & 2.79 \\
\hline Rising cost of labour & 3.75 & 4.00 & Size of domestic market / proximity to market & 2.50 & 2.79 \\
\hline High transport costs & 3.33 & 3.92 & Social license to operate & 0.83 & 2.60 \\
\hline Market volatility & 2.50 & 3.75 & Lack of port facilities & 0.83 & 2.58 \\
\hline Fluctuations in exchange rate & 3.33 & 3.71 & Geopolitical uncertainty & 0.42 & 2.58 \\
\hline Environmental concerns & 2.92 & 3.63 & Disposal of slag & 2.08 & 2.38 \\
\hline Low productivity of workforce & 2.08 & 3.58 & Poor project execution & 0.42 & 2.29 \\
\hline Restricted access to capital & 3.75 & 3.54 & Low efficiency & 0.00 & 2.17 \\
\hline Unrest / volatility in workforce & 1.25 & 3.46 & Competing demands for land use & 0.83 & 2.13 \\
\hline Skills shortage & 2.92 & 3.46 & Access to water & 0.42 & 2.08 \\
\hline Lack of railway capacity & 0.83 & 3.421 & Anti-dumping duty & 1.67 & 2.04 \\
\hline Unreliable electricity supply & 3.33 & 3.416667 & Scarcity of resources & 0.42 & 2.04 \\
\hline Lack of research and development & 2.92 & 3.33 & Obtaining mining license & 0.83 & 1.71 \\
\hline Resource nationalism & 1.25 & 3.25 & Mining Charter concerns & 0.42 & 1.52 \\
\hline Underdeveloped technology & 1.25 & 3.04 & & & \\
\hline
\end{tabular}

which in turn could provide policy-makers, government, or other industry stakeholders a guide as to which barriers to approach first when considering interventions. The barriers are categorized according to their respective severity (y-axis) and prevalence (x-axis) scores into four quadrants as indicated in Figure 11.

\section{Framework validation}

The framework was validated through application to a case study and expert analysis to determine the usefulness and value of such a framework. The validation was done in two parts:

\section{Using the South African manganese industry as a case} study - The full capacity of the barrier identification framework was used to analyse the industry and identify the barriers to growth faced by role-players from the different sectors comprising the manganese value chain. Each tool of the framework phases was applied during the case study to illustrate the implementation of the framework and its capabilities.

2. Framework validation through expert analysis-The validation analysis was performed through questionnaires and interviews, with five experts from diverse fields. These experts comprised an individual in academia, an individual involved in research related to beneficiation at a research council, a senior expert that has worked throughout the mineral beneficiation industry in various research capacities and advised various policy-making processes related to the minerals industry, one senior analyst with a strategy background working in a company 


\section{Identifying barriers to growth in mineral value chains}

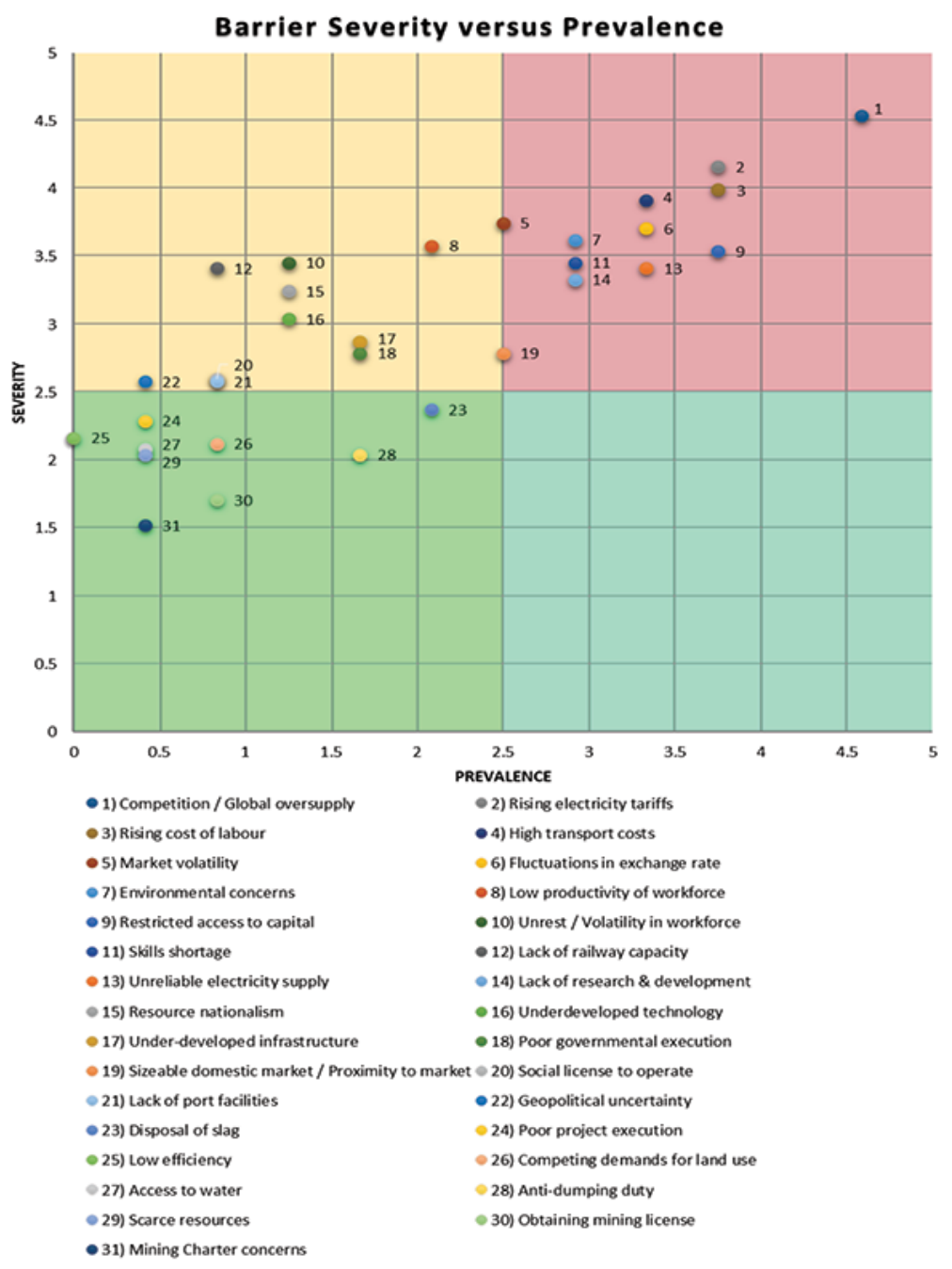

Figure 11-Barriers classified according to their severity and prevalence in the manganese industry

active in the mineral value chain, and one senior manager from the mining industry. Each of these experts added input from a different perspective and made distinctive contributions from their respective areas of knowledge and expertise. This allowed the validity of the different aspects of the framework to be evaluated and refined.

The validation strategy that was followed for this study is shown in Figure 12.

Each of the five experts was given a 23-page validation document that summarized the outline of the framework structure, as well as the theories and methodologies used to develop the framework. The document provided a description of each phase with an explanation of how it should be applied and some of the key outputs of each phase to illustrate its usefulness. The document consisted of a short introduction providing information on the background to the study, followed by an outline of each of the five research phases and concluding with the validation questions. Six validation questions were included in the validation questionnaire. These focused on: the need for the framework, its usefulness, competing frameworks, the strengths of the framework, the shortcomings of the framework, and an open question for any other comments.

All the respondents that took part in the validation process agreed in their answers to the questionnaire that there is a need to identify barriers to economic growth for specific MVCs

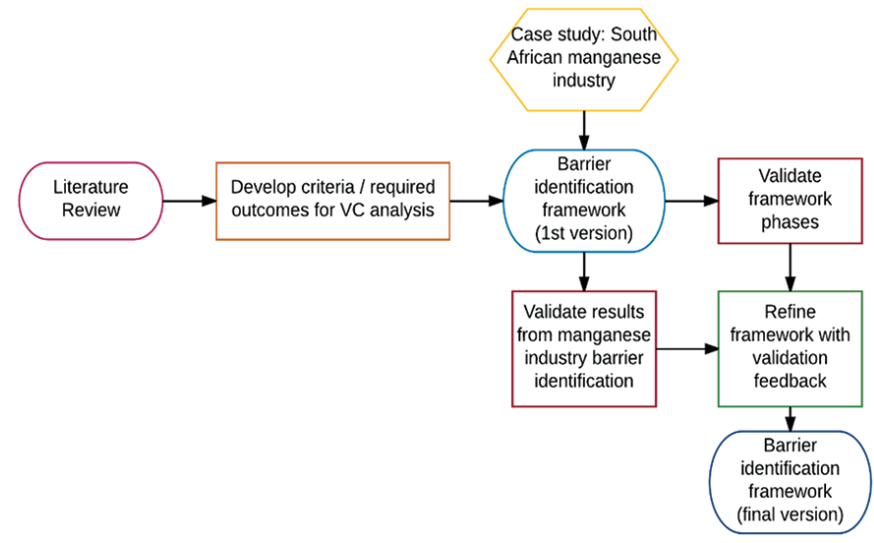

Figure 12-Research validation strategy

and to determine their severity and prevalence. Due to the socio-economic imperative that exists to develop South Africa's economy and since the country's mineral resources play a key role in the economy, it can be concluded that any contributions that can add to the growth of specific value chains are relevant. It was also stated that proper understanding of the barriers to growth in order to support action to address them would be of significant value and is required by policy-makers and stakeholders within the industry. 


\section{Identifying barriers to growth in mineral value chains}

Many of the respondents emphasised the complex challenges that relate to specific aspects in the mineral industries, as well as common challenges that affect industry in general. Investigating the industry from a value chain perspective provides an advantage of understanding holistically where the constraining factors lie. The respondents concurred that the approach would support a more effective analysis and provide a useful methodology and practical approach with tools that the relevant stakeholders could use individually and collectively.

The framework was noted for its differentiation approach between the various sectors by analysing barriers for each of the sectors along the value chain, as well as the effort to incorporate the value chain in a holistic manner, which included considerations of issues that are not apparent from typical market studies. Another unique contribution is the fact that the barriers are derived directly from the industry and from individuals who work in and understand the mining and commodity industry. The framework was overall described as a very logical and systematic approach to a multi-faceted and complex subject. The framework results were deemed to capture the essence of the challenges involved. Furthermore, the ranking of the barriers in the different sectors was deemed credible and a good basis to build on if this type of effort can be continued further with support from all the relevant stakeholders.

Despite the generally positive feedback, experts from different fields within the mineral industry identified various aspects of the framework that could be improved in future research. Firstly, it was noted that by quantifying the impact of specific barriers, more informed policy decisions could be made. Secondly, a sense of the main cost drivers in the different sectors of the value chain could provide a more nuanced understanding of the sensitivity of different sectors to changes in the prices of key inputs. Thirdly, some of the tools included in the analysis duplicate results. Tools can be better integrated to ensure that the same insights can be attained in less time. Finally, the effects of proprietary technology in different processing steps were not considered.

\section{Conclusions}

A framework was designed to identify and describe the mineral value chain (MVC) environment, identify barriers in the MVC, and rank the barriers in severity. The goal is to improve the efficiency by which, researchers, policy-makers, and other stakeholders can evaluate the binding constraints on an MVC in order to formulate effective responses to address these constraints. Different approaches for describing and investigating value chains were reviewed in order to identify the current research gap and limitations of similar frameworks for the identification of barriers. These limitations were addressed through the inclusion of tools to fulfil each of the framework requirements. The tools were partitioned into five framework phases, with each phase focusing on a specific element of analysis.

In order to convey the utility of the framework, it was applied to a case study of the South African manganese industry. Four different production sectors were identified in the chain within the scope of the study, namely the mining, alloy manufacturing, EMD, and EMM production sectors. Through an iterative process of interviews and surveys, 31 barriers to growth were identified across these four sectors, with global oversupply being the most significant impediment at the time (due to the end of the resource boom causing a general reduction of demand and the subsequent reduction of prices for most of the mineral-related industries), followed closely by the rising costs of electricity, labour, and transport.

Through expert analysis based on the results from the case study, it was concluded that the framework successfully facilitates the identification of barriers within an MVC. The validators concurred that the proposed framework addresses a specific need within the industry and is a useful tool for its stakeholders. The holistic and systematic approach to a multi-faceted and complex subject was identified as the primary strength of the framework.

During the execution of the study, various aspects were identified that require further investigation. Firstly, the research relied on a narrow definition of the value chain, now taking into account side-stream linkages. This could be explored in further investigations. Secondly, the study sought to triangulate information in order to reduce bias. This included making use of interviews, questionnaires, and secondary data. However, the choice of secondary data, interviewees, and perceptions scales necessarily influenced the results of the study. In particular, the inputs from industry stakeholders allow for a detailed and prospective view of the industry and its challenges; however, this does provide an opportunity for manipulation. Triangulation was also hampered by the fact that certain sectors of the value chain had only a single company operating in South Africa, thus severely limiting the potential sample size. Further studies that investigate the potential bias that these choices could introduce in a study such as the one presented here, and how it might be further reduced, could be warranted. Thirdly, certain barriers were somewhat broad in definition, e.g. social license to operate. These might then be difficult to address as the definitions are imprecise. It is recommended that this should be explicitly avoided in future work.

\section{References}

AlBA, E.M. 2009. Extractive Industries Value Chain - A Comprehensive Integrated Approach to Developing Extractive Industries. Extractive Industries for Development Series, no. 3 (March). World Bank, Washington, DC. https:// openknowledge.worldbank.org/handle/10986/18400

BAM, W. and DE BRUYNE, K. 2017. Location policy and downstream mineral processing: A research agenda. Extractive Industries and Society, vol. 4, no. 3. pp. 443-447. https://doi.org/10.1016/j.exis.2017.06.009

BAM, W. and DE BRUYNE, K. 2019. Improving industrial policy intervention: The case of steel in South Africa. Journal of Development Studies, vol. 55, no. 11. pp. 2460-2475. https://doi.org/10.1080/00220388.2018.1528354

CALlaghan, C. 2013. Mineral resource based growth pole industrialisation - Growth poles and value chains. https://www.researchgate.net/profile/Christopher_ Callaghan2/publication/263129235_Mineral_Resource_Based_Growth_Pole_ Industrialisation_-_Ferrous_Metals_Report/links/00b49539ff588e4212000000/ Mineral-Resource-Based-Growth-Pole-Industrialisation-Ferrous-Metals-Report. pdf

CoE, N.M., Dicken, P., and Hess, M. 2008. Global production networks: Realizing the potential. Journal of Economic Geography, vol. 8, no. 3. pp. 271-295. https:// doi.org/10.1093/jeg/lbn002

D'Harambure, A. 2015. Overview of the Global Manganese Industry. Proceedings of the 16th Asial Ferro-Alloys Conference, Singapore, 31 March -2 April. https:// www.metalbulletin.com/events/download.ashx/document/speaker/7742/ a0ID000000X0kCwMAJ/Presentation

Department of Mineral Resources. 2011. A beneficiation strategy for the minerals industry of South Africa. Pretoria. pp. 1-23.

Edinger, H. 2014. Outlook of South Africa's Manganese Sector, May. Frontier Advisory. 


\section{Identifying barriers to growth in mineral value chains}

EY. 2013. Business risks facing mining and metals 2013-2014. http://www. ceecthefuture.org/wp-content/uploads/2013/12/Business_risks_facing_mining_ and_metals_2013-2014_ER0069-1.pdf

EY. 2019. Top 10 business risks facing mining and metals in 2019-20. https:// assets.ey.com/content/dam/ey-sites/ey-com/en_gl/topics/mining-metals/ mining-metals-pdfs/ey-top-10-business-risks-facing-mining-and-metalsin-2019-20.pdf

FICCI (Federation of Indian Chambers of Commerce and Industry). 2014. Using steel slag in infrastructure development. http://blog.ficci.com/archives/5291/5291

Ford, K., Hobbs, D., and Urouhart, R. 2007. CIS ferro alloys industry: Commercial opportunities, technical challenges and strategic implications. Proceedings of Infacon XI: Innovation in Ferroalloy Industry, New Delhi, India, 18-21 February 2007. https://www.pyrometallurgy.co.za/InfaconXI/038-Ford.pdf

Gajigo, O., Mutambatsere, E., and Adjei, E. 2011. Manganese industry analysis: Implications for project finance. Working Paper no. 132. African Development Bank. https://www.afdb.org/en/documents/document/working-paper-132manganese-industry-analysis-implications-for-project-finance-24162

GEREFFI, G. 1994. The organization of buyer-driven global commodity chains: How US retailers shape overseas production networks. Commodity Chains and Global Capitalism, January 1994. pp. 95-122. https://doi. org/10.1177/0730888405277964

GEREFFI, G. 2011. Global Value Chain Analysis and Its Implications for Measuring Global Trade. https://unstats.un.org/unsd/trade/presentations/wed-am/garygereffi

GEREFFI, G. 2019. Global value chains and international development policy: Bringing firms, networks and policy-engaged scholarship back in. Journal of International Business Policy, vol. 2, no. 3. pp. 195-210. https://doi. org/10.1057/s42214-019-00028-7

GerefFi, G. and FernAndez-STARK, K. 2011. Global value chain analysis: a primer. Center on Globalization, Governance \& Competitiveness. Durhan, NC.

Gereffi, G., Humphrey, J., and Sturgeon, T. 2005. The governance of global value chains. Review of International Political Economy, vol. 12, no. 1. pp. 78-104. https://doi.org/10.1080/09692290500049805

GerefFI, G. and LeE, J. 2012. Why the world suddenly cares about global supply chains. Journal of Supply Chain Management, vol. 48, no. 3. pp. 24-32. https:// doi.org/10.1111/j.1745-493X.2012.03271.x

Gilberthorpe, E. and Papyrakis, E. 2015. The extractive industries and development: The resource curse at the micro, meso and macro levels. The Extractive Industries and Society, vol. 2, no. 2. pp. 381-390. https://doi.org/10.1016/j. exis. 2015.02 .008

GLobal SLAG. 2015. Korea develops cement from reduced metal slag. https://www. globalslag.com/news/item/16-korea-develops-cement-from-reduced-metal-slag

Hausmann, R., Klinger, B., and Lawrence, R. 2008. Examining beneficiation. CID Working Paper Series, no. 162. pp. 1-25. http://www.cid.harvard.edu/ southafrica

Hirschman, A.O. 1981. Essays in Trespassing: Economics to Politics and Beyond. Cambridge University Press.

Humphrey, J. and Schmitz, H. 2001. Governance in global value chains. IDS Bulletin. https://www.ids.ac.uk/files/dmfile/humphreyschmitz32.3.pdf

HumpHreys, D. 2013. New mercantilism: A perspective on how politics is shaping world metal supply. Resources Policy, vol. 38, no. 3. pp. 341-349. https://doi. org/10.1016/j.resourpol.2013.05.003

International Manganese Institute. 2014a. 2013 Annual Report. Paris, France.

International Manganese Institute. 2014b. Essential manganese. Annual Review 2014. Paris, France.

InTERnATIONAL MANGANese Institute AND RPA. 2015. Manganese: The global picture - A socio economic assessment. Report for the International Manganese Institute. Paris, France.

KAHN, M. 2013. Natural resources, nationalism, and nationalization. Journal of the Southern African Institute of Mining and Metallurgy, vol. 113, no. 1. pp. 3-9. http://www.scielo.org.za/scielo.php?script=sci_ arttextandpid=S2225-62532013000100004

KAPLINSKY, R. and MorRIS, M. 2001. A Handbook for Value Chain Research. IDRC. http://www.prism.uct.ac.za/Papers/VchNov01.pdf

KAplinsky, R., MoRris, A., and Kaplan, D. 2011. Commodities and Linkages : Industrialisation in Sub- Saharan Africa. Centre for Social Science Research (CSSR), University of Cape Town. http://hdl.handle. net/11427/19295

MMC. 2016. Manganese Metal Company. Nelspruit, South Africa.

Neilson, J., Pritchard, B., Fold, N., and Dwiartama, A. 2018. Lead firms in the cocoa-chocolate global production network: An assessment of the deductive capabilities of GPN 2.0. Economic Geography, vol. 94, no. 4. pp. 400-424. https://doi.org/10.1080/00130095.2018.1426989

OECD, WTO, And World Bank Group. 2014. Global Value Chains: Challenges, Opportunities, and Implications for Policy. Report prepared for submission to the G20 Trade Ministers Meeting, Sydney, Australia, 19 July 2014. https://pdfs. semanticscholar.org/f482/08032b3e6f9c981497dcf88a2d57d1f7cc75.pdf

Olsen, S.E., TAngstad, M., and Lindstad, T. 2007. Production of Manganese Ferroalloys. Tapir Academic Press,Trondheim, Norway:

Pooe, R.I.D. and MHelembe, K. 2014. Exploring the challenges associated with the greening of supply chains in the South African manganese and phosphate mining industry. Journal of Transport and Supply Chain Management, vol. 8, no. 1. pp. 1-9. https://doi.org/10.4102/jtscm.v8i1.139

PORTER, M.E. 1985. The Competitive Advantage: Creating and Sustaining Superior Performance. Free Press, New York.

RAтsномо, K. 2013. South Africa's Manganese Industry Developments 2004-2011. Directorate: Mineral Economics, Pretoria.

SACHS, J.D. and WARNER, A.M. 1995. Natural Resource Abundance and Economic Growth. Nber Working Paper Series, no. 5398. https://doi.org/10.3386/w5398

Schmiтz, H. 2005. Value Chain Analysis for Policy-Makers and Practitioners. International Labour Organization, Geneva, Switzerland.

STIJN, J.-P.C. 2005. Natural resource abundance and economic growth revisited. Resources Policy, vol. 30, no. 2. pp. 107-130. https://doi.org/10.1016/j. resourpol.2005.05.001

Sturgeon, T.J. and GerefFi, G. 2009. Measuring success in the global economy: international trade, industrial upgrading, and business function outsourcing in global value chains. United Nations Conference on Trade and Development, Geneva. https://unctad.org/en/docs/diaeiia200910a1_en.pdf

UNCTAD. 2013. World Investment Report 2013: Global Value Chain: Investment and Trade for Development. United Nations, New York and Geneva.

US International Trade Commission. 2003. Electrolytic manganese dioxide from Australia, China, Greece, Ireland, Japan and South Africa. https://www.usitc. gov/publications/701_731/pub3633.pdf

VAN ZyL, H., BAm, W.G., and SteEnKAmp, J. 2016. Identifying barriers faced by key role players in the South African manganese industry. Proceedings of the 27th SAIIE Annual Conference. pp. 1-15. Southern African Institute of Industrial Engineering

Von BeLow, M.A. 1992. Planning for future ferroalloy production in South Africa. INFACON 6: Proceedings of the 6th Internatinal Ferroalloys Congress, Cape Town. Volume 1. Southern African Institute of Mining and Metallurgy, Johannesburg. pp. 261-268. https://www.pyrometallurgy.co.za/ InfaconVI/1261-VonBelow.pdf

World Steel Association. 2014. World Steel in Figures 2014.. Brussels, Belgium: https://www.worldsteel.org/en/dam/jcr:17354f46-9851-45c2-a1b6a896c2e68f37/World+Steel+in+Figures+2014+Final.pdf 


\section{Identifying barriers to growth in mineral value chains}

\section{Appendix A: Framework phases}

Table X provides an overview of the various framework phases. This includes the aim description and outcome of each phase.

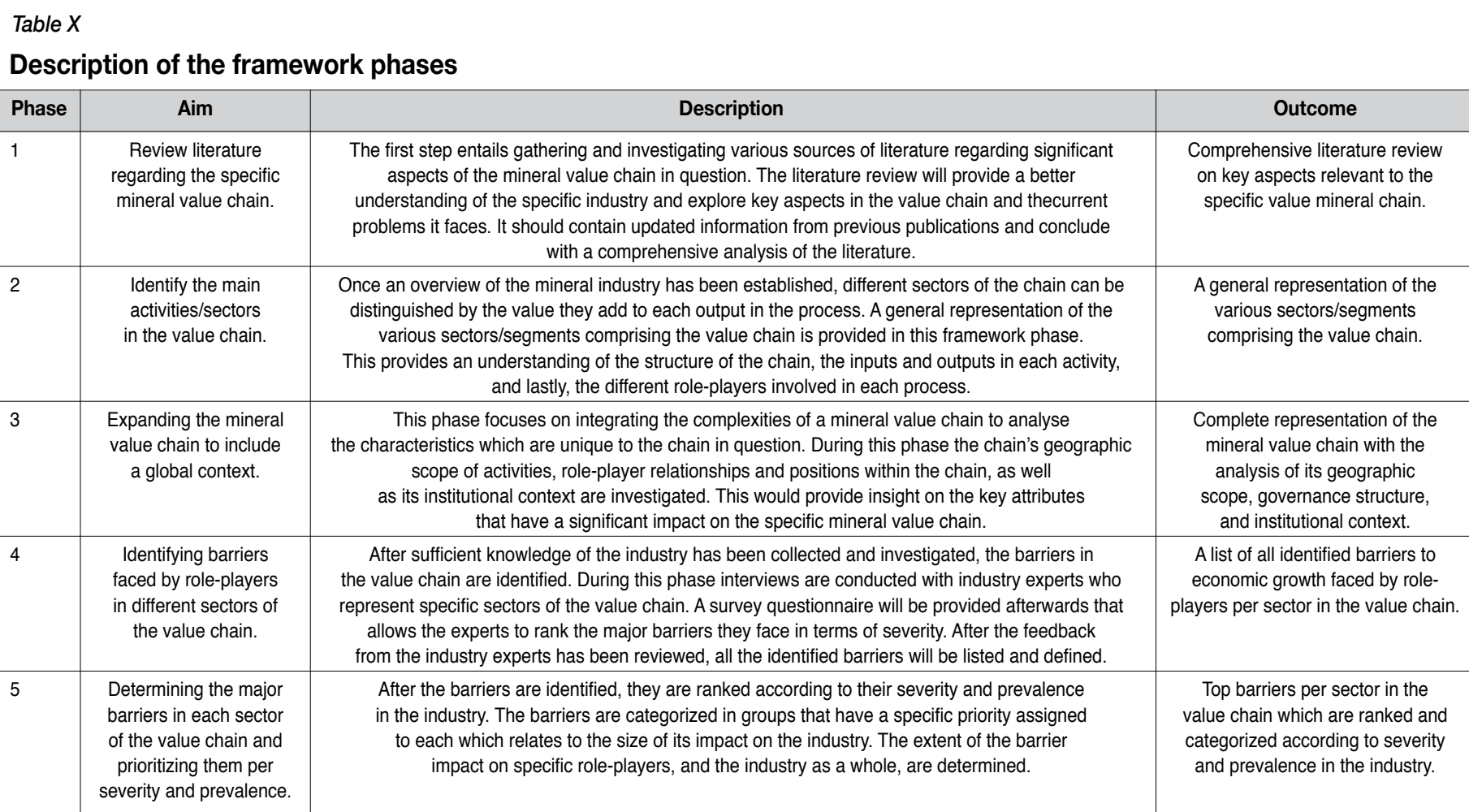

\section{Appendix B: Delphi process}

Table XI provides a summary of the Delphi process used to identify and rank the barriers in the research.

\section{Table XI}

\section{Summary of the Delphi process used}

\begin{tabular}{|c|c|c|}
\hline Round & Step & Description \\
\hline \multirow{4}{*}{$\begin{array}{l}\text { Round 1: Generation of } \\
\text { initial barriers }\end{array}$} & Step 1 & Determine questions for interview guide. \\
\hline & Step 2: Interview & Conduct interviews with respondents \\
\hline & Step 3: Interview (continued) & Respondents discuss different aspect of the company's operations that might encounter constraining factors \\
\hline & Step 4 & Researcher distils all the responses and creates initial list of barriers \\
\hline \multirow{8}{*}{$\begin{array}{l}\text { Round 2: Review and } \\
\text { finalize barriers }\end{array}$} & Step 5: List of barriers \#1 & Researcher mails first list of barriers to respondents. Questionnaire items are obtained from the generative round \\
\hline & Step 6: Feedback \#1 & Respondents review initial list of the barriers \\
\hline & Step 7 & Respondents are encouraged to add to the list of barriers as well \\
\hline & Step 8 & Respondents rank the barriers according to severity \\
\hline & Step 9 & Finalize barrier list from respondents' input \\
\hline & Step 10 & Complete list by adding barriers identified prior to interviews to the list \\
\hline & Step 11 & Define each barrier to avoid definition overlap. \\
\hline & Step 12: List of barriers \#2 & Group similar barriers in clusters \\
\hline \multirow{4}{*}{$\begin{array}{l}\text { Round 3: Barrier } \\
\text { severity survey }\end{array}$} & Step 13 & Set up the survey with all of the barriers and a corresponding scale to score the severity for each \\
\hline & Step 14: Survey & Respondents score each barrier with a score between 1 and 10 (or n/a) regarding severity \\
\hline & Step 15 & Researcher accumulates all the scores per sector \\
\hline & Step 16: Ranking of barriers & Researcher ranks the top 10 barriers per sector from the respondents' input \\
\hline \multirow{5}{*}{$\begin{array}{l}\text { Round 4: Finalize survey } \\
\text { results }\end{array}$} & Step 17: List of barriers \#3 & The rankings of the barriers are sent to the respondents \\
\hline & Step 18 & The respondents review the final results \\
\hline & Step 19 & Analyse feedback \\
\hline & Step 20 & Determine if consensus is reached \\
\hline & Step 21 & Finalize rankings \\
\hline
\end{tabular}

